\title{
CUSTOMS AND RITES OF THE REGIONS OF UZBEKISTAN
}

\author{
Guzal Khalikulova
}

\section{uzdsmi@mcs.uz}

\author{
State Institute of Arts and Culture, Uzbekistan
}

\begin{abstract}
The given article deals with the fact that in the Pskent and Buka districts of the Tashkent region there were unique rituals, people of these localities were engaged in handicraft, weaving, needlework, animal husbandry and they created ancient songs associated with these phenomena, various events were sung by folklore songs and they passed from generation to generation contributed to the familiarization of people to beauty.

Keywords: Customs; Tradition; National Songs; Culture; History; Region; Oral History
\end{abstract}

\section{ОБЫЧАИ И ОБРЯАЫ РЕГИОНОВ УЗБЕКИСТАНА ${ }^{1}$}

\author{
Гузаль Халикулова
}

ГосуАарственный институт искусств и культуры, Узбекистан

Резюме: В Аанной статье речь велётся О том что в Пскентском, Букинском районах Ташкентской области существовали своеобразные обряды, АюАи этих местностей занимались ремесленничеством, ткачеством, руколелиям, животновоАством и они созАали Аревние песни связанные С этими яв^ениями, различных мероприятие пели фольк^орные песни и они перехолив из поколения в поколение способствовали приобщению АюАей к красоте искусства пения.

КАючовие слова: обряды; обычай; народные песни; культура; история; район; устная история

Республика Узбекистан расположена на обширный территории СреАней Азии и имеет несколько культурных регионов с своеобразным развитием, что особенно наблюАается в традиции фольклора, обрядах и обычаях. Ааже на территории отлельных районов также, встречаются эти феномены. Горола Пскент, Бука Ташкентской области Узбекистана является Аревними культурными местностями, гАе роАИАись много народные песни, связанные с их обычаями и обрядами. Жители этих

' В статье публикуются результаты Аоклала, представленного на конореренции LCH 2019 
регионов занимались ремесленничеством, ткачеством, портняжным Аелом, кузнечным ремеслом, животноводством и Аругими ремеслами, и в процессе этих ремесе^ слагали фольклорные песни и придумали музыку этим песням, к тому же еще их исполняли высоким мастерством. А также были такие ^юАи, которые сочиняли и Аекламировали стихотворения.

ОАнако редко встречаются письменные источники об истории, культуре обычаях и обрядах Пскентского района. В Аанное время такие письменные источники, как Аиссертация ученой Музайяна Алавия тему «об узбекских песнях» (1959), ее монографиии «Узбекские народные песни», "Узбекские народные традиционные песни", книга ученогоисторика "Из истории Пскента" (2010). ОАнако в таком условии можно опираться и на устную историю. Потому что крупные исторические книги также созАаются на основе устной истории.

В Пскентском районе древние свалебные церемонии имели своеобразную специфоку, они отличались увлекательными обычаями и обрялами, играми. ОАнако многие обычаи и обрялы, к сожалению, забыты. КажАый обычай и обрял имеет свое глубокое значение. Моя мама много рассказала об этике Аевушек, чести и Аостоинстве парней. Она также рассказала о своеобразном провелении прежних свалебных торжеств в нашем кишлаке и все проводимые обряды на этих свальбах меня уАивили. Я не фольклорист, но Аумаю, что Ао наших Аней еще не исследованы народные обычаи и обряды, одежды, церемонии, традиции населения Ташкентской области (Murodov, 1994), (Nazarov, 2011), (Juraev and Khudoikulov, 2008), (Mamatkulov, 2010).

В районах Ташкентской области своеобразно проволились свальбы конгломератов. Прежние свальбы кишлаков Саил, О^тиовуль Якалов, Чимкурган и Аругие резко отличались от современных.

После сосватании девушки и парня проведен обрял «разламывание лепешку». После этого каждый вечер родственники семей молодых систематически навестили Аруг-Аруга. Начинается полготовка к свальбе. Женщины родственники проводили обряды «Пристегивание олеяла». Из бекасама, сатина, кирпсатина, шелка, атласа и Аругих материалов простегивали ватные олеяла. Так женщиныродственницы несколько Аней устраивали хашар по пристегиванию 
ватных одеялов. Хозяева Аома угощали их изысканными блюАами. А

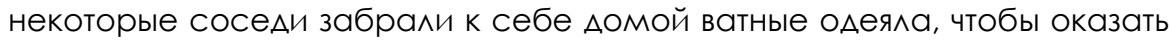
бескорыстную помощь. Швеи маха^^и сшивали рубашки, безрукавки и Аругие олежлы невесты и чапан жениха. Невеста сама ткала носовой платок, тесьму. Кушак украшали различным символическими знаками с помощью цветных ниток. Это стало символом АобрососеАских отношений. После определения Аня свадьбы в Аоме невесты проводили обрял «Осмотр придания». Комнату невесты украшали полготовленными одежАами и предметами Аля нее. СунАук покупали у мастеров города Пскент или Букинского района. На сунАук аккуратно складывали ватные олеяла и курпачи. Эту залачу осуществили в основном бабушка невесты. И она кажАый раз когАа склаАывала ватные олеяла и курпачи выражала добрые намерения. Эти намерения громко произносились. И всегАа, когАа было выражено онно Аоброе намерение, окружающие подлержали ее со словами «омин». Сваха невесты на протянутую проводку или шнур повесила все руколельные вещи невесты. СреАи них можно было увилеть вещи, которые были оставлены на память невесте женщинами-родственниками старшего поколения как мобрая память. СреАи готовых олежА вилны и вещи матери, они таят в себе доброе намерение - невеста сама сошьет из этих матерей себе олежлу когла булет беременной. Безрукавки тоже Аекорируются различными орнаментами.

Во дворе готовятся к встрече жениха. Проводят генеральную уборку, Авор блестит как зеркало. На супе силят уважаемые старикиродственники, молодые обслуживает их. Установлены огромные котлы и самовары. Все эти мероприятия организуются к вечеру, после работы. Вечером жених с своими Арузьяи прихолит в гости к невесте.

В середине Авора разжигают костер и встречают их. Они три раза обходят вокруг костра, и стоят в стороне. Аойра, сурнаи приглашают своих к танцам. Жених и его друзья подАерживают их. Старухи раскилают конореты. Их с шумом собирают Аети. Затем свахи приглашают жениха и его Арузей зайти в Аом. ПереА угогщением еще проводятся различные обряды. На олну сторону сялут невеста и ее сваха, в Аругую сторону - жених и его друзья. Начинается рассказ газели - стихотворений. Ао свальбы жених и невеста не видят Аруг-Аруга. В этом 
мероприятии тоже они не видят Аруг - Аруга. Арузья жениха его посадят назал и огораживают его. В это время подруги невесты тоже огораживают ее, чтобы жених не видел ее. Начинается рассказывание бейтов, которого первым начнет полруга невесты. Она наливает чай в пиалу и встает. В это время жених хочет взглянуть в невесту, олнако ее лицо было закрыто платочкой. Полруга невесты рассказывает газель и протягивает пиалу с чаем Аругу жениха:

Аарё^арнинг ул юзила уйларингиз,

Оқариб кўринали бўйларингиз.

ИпмиАИ, ипакмиАИ КИйганингиз,

БизАан хам ортиқмиАи суйганингиз.

Аруг жениха не берет пиалу и знаком указывает на жениха. Пиала полается жениху. Основная цель зАесь чтобы невеста услышала голос жениха. По условиям этого обряла жених обязательно Аолжен рассказать бейт. Он рассказывает:

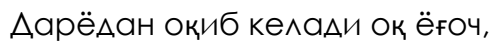

Оқ ёғочга қўниб келар қалАирғоч.

қалАирғоч қанотиАан қайрилмасин,

хар киши севганилан айриммасин.

Жених знаком указывает на невесту, желает показать, что желает вилеть ее, выпьет чай и вернет пиалу подруге. Все хвалят жениха: "Молодец!", "Слава жениху!". Рассказывание стиха прололжается. Снова в пиалу наливают чай, следующая подруга невесты подает ее Аругу жениха. Аевушка:

Им билан, им билан,

Ўраб олай сим билан.

Мени кўнгАим сиз билан.

Сиз кетасиз ким билан.

Чтобы выиграть стихотворный поеАинок Аевушка полает пиалу с чаем парню, который не сумеет рассказать стихотворение. Такие парни, естественно, не задумываясь берут чай, выпьют, и из кармана Аостают из кармана носовой платок, и в углу его привязывают Аеньги или колечко, и притягивает к девушке, сказав, что “ответ в узелке". Аевушке похлопают с возгласом и спешат посмотреть что привязано в узелке... 
По рассказам моей мамы, полобные стихотворные соревнования проАолжались Аолго. В этом отношении мо^оАёжь бы^о находчивой, и чтобы не попасть в неулобное положения на свалебных торжествах они заучивали наизусть стихотворения.

После стихотворного соревнования, мололёжь перехолила к Аругой игре. Это игра называлась «браться за руку». Полружки обматывают руку невесты красивым платочком и притягивают в сторону жениха. Жених тоже притягивает руку, жених и его Арузья к следующей игре приглашают девушек. Пока не выигрывает представители жениха игра продолжается. Например, в игре «Притяжение» в середине комнаты расстилается ватное одеяло. Невеста со своими полругами строятся на одной стороне, на Аругой стороне жених со своими Арузьями, они притягивают Аруг-Аруга Аержа за талию. Невеста и жених сидят на своём месте. На этой игре, естественно, выигрывают парни. Затем полруги со свахи невесты накрывают стол. На Аастархане различные слалости, ^епёшки, чучвара, шурпа из грудинки. Сваха на руке областа, а на плече плотенце: жених и его Арузья моют руку. Они благодят за эту услугу свахи. После шурпы раздается плов. После угощения начинается игра «Подача кушака». Это игра также начинается со стихотворения.

Аевичница завершается этой игрой.

На следующий Аень сваха Жениха олевают в белый яктак, тюбетейку, халат-бекасам, Аойра и сурнаем, на арбе или пешком уводят невесту Аомой. ОАнако переА ухолом жениха и его Арузей застави^и АОАго поА музыкой жАать невесту. Этим ОНи хотеАи, чтобы жених Аолго уважал свою жену. Аевушки нарядно одевают невесту. Красиво офрормленная белая шелковая рубашка, штаны из этого же материала, волосы красиво заплетены.

На ногу олевали новые красивые ичиги, галоши. На голову олевали красивый шелковый платок. Мать и бабушка еще на голову невесты накинули паранджа, которого когАа-то они сами и выражали пожелание, чтобы невеста так же как они сами жила Аолго и счастливо, и имела много детей. Как отмечено выше, невесту увели или на арбе, или пешком со свалебной песней «Ёр-ёр», Арузья жениха несли фокели. 
Моя мама говорила, что «ёр-ёр» во всех регионах пели олинаково. Но свалебная песня в городе и в селе немного различались. А в нашем кишлаке по-особому пели. Те кто пели свалебные песни шли впереди, остальные сзали. Невеста сама тоже участвовала при запеве «Ёp-ёр».

Моя мама взяла Аойра и приятным голосам нача^о петь «Ёрёрı...

Ёр-ёр айтсам-а, ёр-ёрчилар лейли мани,

Ёр-ёрай Аейли мани.

Аалалаги оч бўрилар-а ейли мани,

Ёр-ёрай ейли мани.

қат-қат^ама қат^ама-ё қатланали,

Ёр-ёрай қат^анали.

Қизни олиб янгалари-ё от^анаАи,

Ёр-ёрай от^анали.

Қизни олиб янгалари тура турсин,

Ёр-ёрай тура турсин.

Оқ сут берган онаси-ё рози бўлсин,

Ёр-ёрай рози бўлсин.

қиёмат^и отаси-ё қози бўлсин.

Ёр ёрай қози бўлсин.

Аевушка:

Уйингизнинг эшигиАан ўтАим ота,

Ёр-ёрай ўтАим ота.

Кўп кўрганинг мен бўлсам-о кетАим ота,

Ёр-ёрай кетАим ота.

Отам мени ўрнимга-ё бодом эксин.

Ёр-ёрай болом эксин.

БоАОм шохи эгиАганАа мени Аесин

Ёр-ёрай мени Аесин. (Йиғлайли.)

Певица:

Ши^Аир-шилАир қамишга-ё сирғам тушАи,

Ёр-ёрай сирғам тушАи.

Синамаган йигитга-ё синглим тушАи,

Ёр-ёрай синглим тушАи. 
Синглим учун қовурғам-о қайишали,

Ёр-ёрай қайишали.

Ўнг қўлимАа ти^^о Узиг-о майишаАи.

Ёр-ёрай майишаАи.

ЙИғАаманг қиз ЙИғАаманг-О туй СИзнинг,

Ёр-ёрай туй сизнинки.

Остонаси ти^^оАан-О Уй СИзникИ,

Ёр-ёрай уй сизники.

Аевушка:

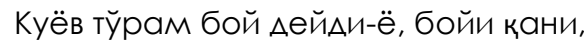

Ёр-ёрай бойи қани.

Самоварда қайнаб турган чойи қани,

Ёр-ёрай чойи қани?

Сув хам бўлса ичайлиг-о чой ўрнига.

Ёр-ёрай чой ўрнига.

Чит хам бўлса кияйлиг-о, шойи уурнига.

Ёр-ёрай шойи уурнига.

Певица:

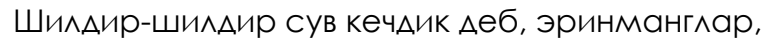

Ёр-ёрай эринманглар.

Ўн беш минг сўм берлик Аеб-о, керишманглар.

Ёр-ёрай керишманглар.

Ўн беш мингни уйимизга таш^аб ке^Аик,

Ёр-ёрай таш^аб ке^Аик.

Тўлган ойАек қизимизни бошлаб келАик,

Ёр-ёрай бошлаб келАик.

Тўлган ойАек сингАимиз-о бахтАи бўлсин,

Ёр-ёрай бахтли бўлсин.

Умри узун, юзга кириб-о ёшли бўлсин,

Ёр-ёрай ёшли бўлсин.

Ўғил-қизи ўнта бўлиб, тахтли бўлсин,

Ёр-ёрай тахт^и бўлсин.

Taк $А$ Аома жениха по пути звуча^ «ёр-ёр». Во Аворе жениха многолюАно. ПоА звуками Аойры, сурная танцуют свахи. ОАна сваха танцует в роли жениха, другая в роли невесты. Вокруг веселились, 
хлопали, шутили Аруг-Аругом. В середине Авора горит костёр. За четыре угла палака держат четыре Аевушки. Пол палаком невеста шагает вокруг костра. Рялом с невестой сваха. Если четыре Аевушки устают нести палак, их заменяют Аругие Аевушки. Певица поет пок^он невесты, а невеста поклоняется всем. Все стоящие по обеим сторонам принимают поклон невесты и желают добрые пожелания. В настоящее время традицию поклона невесты проводят по своему. Раньше эти пок^оны точно алресовались родственникам жениха и невесты.

Невеста входит в свою комнату. Половина комнаты преграждены декоративным материалом. Занавес тоже сшить самой невестой или ее матерью. Начинаются еще интересные обряды. За Занавесом подготовлено место Аля Авоих. Аве старухи ^ягут на это место. Обрял называется «Умерла старуха». К занавесу полводят невесту и жениха.

- Кто на нашем месте ^ежит? - спрашивают.

- ^ежат девушки, - отвечают старухи.

- Аевушки живые или мертвые? - еще спрашивают свахи.

- Мертвые.

- Нет они живые, свахи дарят подарки старухам и старухи благословляют их. Старухи встают. Сваха край волос невесты полает жениху, жених держит край волос. Это означает что «наша ваша» и невесту с женихом олних оставляют за занавесом. Обрял «Пришла невеста» так завершится.

Как отмечала Тожихон ая Каримова из Букинского района обрялы Ташкентской области не очень сильно отличались Аруг от Аруга. Накануне свальбы жених со своими Арузьями посещают Аом невесты. А^я девушек и парней отводили отлельную комнату. Вокруг Аастархана рассказывали стихи, газели, бейты. Обрялом управляли свахи.

Если хорошо проводят мероприятие, жених дал им подарки. Поэтому они были активными.

Сваха:

Ғазал айтиб чой узатай қўлингизга,

Неча кунАир интизорман йўлингизга.

Куёв бола таниб олинг, янгангизман,

янга бўлиб умиАвормиз тангангизАан.

Жених: 
Чойингизни ичиб бўлАим, рахмат янга,

Янгаларнинг АарАи бўлар Аоим танган.

Қизингизни севиб қолАим, гунохим шу,

СизАан кейин чой узатсин ўзи менган.

(теперь полруга невесты рассказывая стихотворение подает чай Аругу жениха)

Мехмон бўлб кепсиз танишайлАик,

Кулишиб байту-ғазал айтишайлик.

қолиб кетсак уялтирманг асло бизни,

И^тимосИМ айтақолинг ИСМИнгизни.

Мени исмим Искандардир билиб қўйинг,

Ечиб қўйган чопонимни илиб қўйинг,

Сизнинг кўнги^ бизАа бўлса чиройли қиз,

Рўмолингизни кўтариб кулиб қўйинг.

Танимаслан буйруқ бериш инсофрАанми?

Сўрамаслан севАим Аейиш инсофоданми.

Севги умр савАосиАир ўйнашмангиз,

Бир кўришАа севиб қолиб аАашмнгиз.

Аруг жениха:

СўзларимАан қизармасин юзларингиз,

Ёқиб қолАи менга шах^о кўзларингиз.

Мафртун бў^Аим исмингизни айта қолинг,

Шоирмисиз, бунча ширин сўзларингиз.

Аевушка:

Ойсанам Аеб атамишлар отларимиз,

Жағалбайли уруғиАан зотларимиз.

Совчи қўйиб сарсон бўлиб юрманг, йигит,

Санамаслан қиз бермаймиз ётлдарга биз.

Аруг жениха:

Ёт Аемангиз, ёт эмасмиз сизларга биз,

Сизмар ичган буз ариқдан сув ичамиз.

КуттирмасАан айтаверинг шартингизни,

Бу юракАан ўчмас бўлиб жой олАингиз.

Аевушка: Сиз енгАингиз не Аейишим билмай қолАим. 
Аруг жениха: Кўнги^ экан из^аб, сизни топиб олАим.

Аевушка: Ой $А$ алала ўйнаб юрган қиз боламан,

Аруг жениха: Елкаси ер искамаган бўз боламан.

Словом, выше описанные обрялы и обычаи приналлежали только отАельным кишлакам Пскентского района. Сведения, которые Ааются в книгах известных ученых фрольклористов Малика Муралова «Узбекские ценности», Маматкула Ажураева и латифы Худайкуловой "Обрядоведение», естественно происходили из устных рассказов. Хотелось отметить что в настоящее время необходимо собрать сведения об обычаях и обрядах всех регионов нашей республики и созАать книги, гАе отражались бы эти наши национальные ценности.

\section{Аитература / References}

Murodov, M. (1994). Uzbek values. Book 1 - Tashkent: Chulton Publishing, 1994 (In Тајіk) / [Муродов М. Ўзбек қалриятлари. 1-китоб. - Тошкент: Чўлпон нашриёти, 1994]

Nazarov, K. (2011). Axiology (philosophical values). - Tashkent: Academy, 2011 (In Тајіk) / [Назаров қ. Аксиология (қалриятлар фалсафраси). -Тошкент: "Акалемия", 2011]

Juraev, M.; Khudoikulov, L. (2008). Letter of Approval. -Tashkent: Alisher Navoi Uzbekistan National Library Publisher, 2008 (In Tajik) / [Жўраев М., ХуАойқулов ^. Маросимнома. -Тошкент: А^ишер Навоий номидаги Ўзбекистон Мил^ий кутубхонаси нашриёти, 2008]

Mamatkulov, A. (2010). Tablets on the history of Piskent. -Tashkent: Fan, 2010 (In Тајіk) / [Маматқулов А. Пискент тарихилан ^авхалар. -Тошкент: Фан, 2010] 


\section{КУАТУРНО-ИСТОРИЧЕСКО НАСАЕАСТВО: \\ ОПАЗВАНЕ, ПРЕАСТАВЯНЕ, АИГИТААИЗАЦИЯ}

\section{CULTURAL AND \\ HISTORICAL \\ HERITAGE}

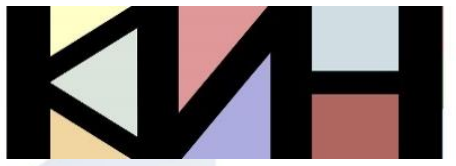

PRESERVATION PRESENTATION DIGITIZATION

\section{Съставители \\ Галина БогАанова Ваня Матеева}

Материалите в сборника са обект на авторско право. Разрешава се безвъзмезАното ползване на техни електронни/ хартиени копия само за лична употреба или обучение, при пьлно цитиране на текущата страница и слеА писмена Аекларация от цитиращия за Аипса на тьрговски намерения. За копиране поА Аруга фрорма, препубликуване или публикуване на сървьри се изисква писмено разрешение и/или заплащане.

() Авторски колектив, 2019 Технически реАактори: Николай Ноев Калина Сотирова-Вълкова Ка^оян Николов

\section{Editors}

Galina Bogdanova Vanya Mateeva

This work is subject to copyright. Open and free of charge use of digital/hard copies of publications is granted only for personal or educational use, with full citation of the current page, and after written declaration of the quoting side for not-commercial Intention. For any other reproducing types, republishing, photocopying, recording, or any other storage retrieval system/ server written permission and/or fee is required.

() Authors` Group, 2019

Technical editors:

Nikolay Noev

Kalina Sotirova-Valkova

Kaloyan Nikolov

\section{Научна поредица: том 5, брой 2 (7)/2019}

Science series: vol. 5 , issue $2(7) / 2019$

www.math.bas.bg/vt/kin

ISSN: 2367-8038 